

\title{
MEDIATING ROLE OF EMPLOYEES JOB ENGAGEMENT FOR RELATION OF EMOTIONAL LABOR WITH LIFE SATISFACTION
}

\author{
Nadeem Akhter ${ }^{1}$, Umar Safder Kayani² \& Muhammad Tahir ${ }^{3}$ \\ ${ }^{1}$ Department of Business Management, The Yanbu University College, Yanbu, SAUDI ARABIA \\ ${ }^{2}$ School of Business Administration, The National College of Business \& Economics, Pakistan \\ ${ }^{3}$ Director Students Affairs, The Lahore Garrison University, Lahore, Pakistan
}

\begin{tabular}{|c|c|}
\hline ARTICLE INFO & ABSTRACT \\
\hline $\begin{array}{l}\text { Keywords: } \\
\text { Emotional Labor, } \\
\text { Employee Job } \\
\text { Engagement, Life } \\
\text { Satisfaction, Baking } \\
\text { Sector, Lahore, } \\
\text { Pakistan }\end{array}$ & \multirow{2}{*}{$\begin{array}{l}\text { Considering the role of life satisfaction of an employee's as vital factor } \\
\text { for employees' performance which directly affects the firms' success, } \\
\text { this study explores the role of emotional labor as an antecedent of life } \\
\text { satisfaction via mediating role of the job engagement of bank officers } \\
\text { working in private and public banks of Pakistan. The sample of } 314 \\
\text { employees of officer rank } 314 \text { employees of banking sector are selected } \\
\text { randomly for data collection. Results of cross-sectional data of } 314 \\
\text { employees working in both private and public sector banks of Pakistan } \\
\text { predict that employees having higher emotional labor have lesser job } \\
\text { engagements, reducing overall life satisfaction of an employee. For } \\
\text { genializing the result this kind of research may include the broad } \\
\text { sample i.e., Islamabad, Bahawalpur, Faisalabad, Multan, and Karachi. } \\
\text { In future this type of research will also be conducted on the telecom, } \\
\text { education, textile sector and education sector. } \\
\text { c) @ @ } 9 \text { ? } 2020 \text { Gomal University Journal of Research }\end{array}$} \\
\hline $\begin{array}{l}\text { Article History: } \\
\text { Date of Submission: } \\
\text { 30-05-2020 } \\
\text { Date of Acceptance: } \\
\text { 18-12-2020 } \\
\text { Date of Publication: } \\
\text { 31-12-2020 }\end{array}$ & \\
\hline Corresponding Author & edu.sa \\
\hline DOI: & \\
\hline
\end{tabular}

\section{INTRODUCTION}

This study conducted by considering the global level organizations as the benchmark, where the organizations have improved employees' engagement. The concept of employee engagement is currently focused as it is affected by different factors like justice system within the organization, emotional positive care, and reluctance. The research analyzes the impact of all other relevant factors on employee engagement. Different other researchers have also studied the concept of employee engagement (Swanberg, McKechnie, Ojha \& James, 2011; Hakanen, Schaufeli \& Ahola, 2008; Slattan \& Mehmetoglu, 2011; Saks, 2006; Lee, Rocco \& Shuck, 2020; Albrecht \& Marty, 2020). According to Mann and Harter (2016) at the moment the whole world is facing the issues related to employee engagement. All the issues may have impact on international organizations. 
Researchers have also described that the top-level management and organizations themselves clearly understand benefits of employee engagement and different organizations have organized different surveys on different periods to analyze the impact of employee engagement (Mann \& Harter, 2016). This factor improves the level of commitment and motivation among employees and that percentage exists from $9 \%$ to $35 \%$ among all the employees working in the different organizations.

It has been witnessed that about $90 \%$ of the sample size trust that employee engagement does have vital relation with the performance of employees. According to Glint (2018), about 60\% of organizations with a high level of the employee engagement achieve the high level of financial performance. Although 39\% of organizations trust that their higher management may focus on employee engagement (Glint, 2018). All of above statements disclose that employee engagement is the most important factor to enhance performance of any organization. According to Gallup (2017), about 33\% of the employees are being efficiently engaged with their work but that ratio hardly improved with only $3 \%$ from the year 2012 to the year 2016. It was also witnessed that a huge number of employees from America like 50\% were not actively engaged with their work or even they were disengaged. This situation may create an ("engagement gap") and that may affect about $\$ 300$ Billion loss on yearly bases in the level of the productivity (Bates, 2004; Chug, 2017). As per the researches of the Gallup and Towers Perrin type agencies, there were 3 out of every 4 employees were not fully engaged in their work at a job (Welbourne, 2007; Khan, \& Lakshmi, 2018; Alexander, 2020). According to the conclusion of the Global Workforce Study in 2012 organizations are not putting and pressing hard the right effort to improve the level of employee engagement.

International research was conducted on 32000 sample size of the full-time employees from different organizations and found that about $35 \%$ of them were fully engaged (Watson, Global workforce study, 2012; Bilal, Yawar \& Zaman, 2020). Similar research was conducted in New Zealand and Australia to understand the level of employee engagement and disengagement and found that 1:1 (Crabtree, 2011). According to Crabtree (2011), about 20\% of employees were fully engaged in Australia, Europe, and New Zealand and about 10\% were engaged in India. A study came with the result of about $21 \%$ population is completely dissatisfied with life and about $21.6 \%$ population is fully satisfied with life and in last, about $54.4 \%$ population may have a moderating level of satisfaction about life (Explained, 2015). In Europe, there is a high ratio where people are dissatisfied with their level of life. Campaña, Giménez and Molina (2020) described that the people with a low level of income are more dissatisfied with their lives. It is also reported in the China, where people with old age seem more dissatisfied ( $\mathrm{Hu}$, Schaufeli \& Taris, 2016). As per the research of Özsoy, Uslu and Öztürk (2014) about half of employees in Turkey particularly in public and private departments were found dissatisfied with their lives. Whole discussion can be concluded with that the satisfaction from life very important for an individual as well as for organization.

\section{LITERATURE REVIEW}

The research variables under considerations have been described in this section along with their interrelationships. From the best of researcher knowledge current research is contributing in the body of the literature by proposing the entire model as single model and also evaluating the mediating role of the employee job engagement for the relation of the emotional labor with life satisfaction. 


\section{Employee Engagement}

Kahn (1990) was the first person, who introduces the concept of employee engagement, and it has multi-dimensions. It is for a long time when Kahn (1990) conducted his basic research paper about "individual engagement" with work, focusing on whether individual is needed to indulge fully in the work or just to remain as the part within the workplace. According to the Macey and Schneider (2008), afterward, engagement is being focused, a quick improvement has generated confusing different definitions of concept to measure, understand and to analyze engagement. It is also being defined as the emotional pride towards the job and considering himself as the luckiest and happiest to work on that task (Thomas, Côté \& Deakin, 2008; Harwood, Knight, Thrower \& Berrow, 2019). The work engagement has been researched in the different contexts including the banking sector with diverse significant outcomes. There are some kind of factors to influence employee engagement among the different other organizations as well. Different researches have elaborated on different factors to affect level of engagement such as leadership, remunerations and rewards distribution, justice within the organization, policy, and procedures and diverse training and development plans (Xu \& Thomas, 2011; Khalaf, Hmoud \& Obeidat, 2019).

It is such a positive thing to have since the engaged employees have been considered as source of inspirations towards the achievement of organizational strategic tasks and objectives. It may generate huge benefits for organizations. As per the different researches, it has been witnessed that improving employee engagement results in improve the loyalty of the employees towards the organization and as a result, the profitability level will be improved. At the same time, it also has positive results for the employees as well with the improvement of self-efficiency and high employees' care (Sundaray, 2011; Mungthanaworakun, Sujitjorn, Suwansak, Wongthongdee, Prempraneerach \& Rugchoochip, 2020). According to Upadyaya, Vartiainen and Salmela (2016), there is a strong positive correlation between employee engagement and life satisfaction. Mache, Vitzthum, Klapp and Danzer (2014) studies that employee engagement has positive significant influence on life satisfaction. The employees' engagement is thus the significant factor that is solely responsible for the success of organizations as engaged employees are more responsible and committed with their assigned tasks and responsibilities in diverse situations. Hakanen, \& Schaufeli, (2012) examines that employee engagement has positive significant influence on life satisfaction.

\section{Life Satisfaction}

According to the life satisfaction concept people only prefer to work to live however they don't even live to work only. In some cases, work may be considered as the tool for personal growth and to fulfill life desires. According to Diener, Lucas, Oishi and Suh (2002) life satisfaction can be elaborated as ("The literature on subjective well-being is about how and why people positively experience their life, including both the cognitive judgment and emotional reactions"). Other researchers said that the mental approach and health is one of important factors being affected by job satisfaction (Veloso, Peralta, Gil, Cornejo \& Castro, 2015). The life satisfaction is a vital phenomenon as it is directly related with the peaceful life of the individuals in their personal as well as professional perspectives. It not only inspires the employees to work with utmost care and diligence but also inspire them to achieve their high-valued tasks leading to higher level of achievements. Life satisfaction is may be considered as emotional feedback by individuals about their lives and leisure time (Sung \& Giannakopoulas 1994; Chung, \& Kim, 2017; Rodríguez, 
Cabrera, Palomino, León \& Esteban, 2020). Therefore, life satisfaction is thus important for the organizations.

Satisfaction is being understood the part of the life satisfaction (Yllmaz, Yılmaz \& Karaca, 2008; Ekinci, 2018; Yu, Sirgy, Bosnjak \& Lee, 2020). The life satisfaction is the accomplishment of life goals, desires, expectations, and life want (Yilmaz et al., 2008; Vural, Yalcinkaya, Celik, Gunduz, Bozan \& Erhan, 2020). Life satisfaction can divide the whole life of an individual (Yilmaz et al., 2008). It is an understanding toward setting the priorities that needs additional care and efforts in attaining the life-goals in a comprehensive manner to guarantee the prosperous life. It is one of the major factors to evaluate the consequences such as solidity and decreased softness and the way forward to understand the state of mind (Lightsey, McGhee, Ervin, Rarey \& Powell, 2013). Life satisfaction is also the attached satisfaction with the certain situation of life but in a way to react as wellbeing with different dimensions such as the high passion and pleasure and to have positivity about the daily life relations (Avsaroglu, Deniz \& Kahraman, 2005; Avşaroğlu, \& Okutan, 2018; Karakuş, \& Kirlioğlu, 2019). Initially, the relation between life satisfaction and the job was identified by Brayfield, Strate and Wells (1957), however, later on, that relationship has been further explored in different contexts and has attained high attention from different researches like qualitative research and quantitative research (Asan \& Erenler, 2008; Korkmaz, 2019).

\section{Emotional Labor}

The concept of emotional labor (management of emotion) was introduced by Hochschild (1979 \& 1983) with certain process to perform any task where the employees take a reference of a set pattern from their social life to manage their emotions as per the expectations even, they don't feel that from inside. In current era that term of emotional labor considered very comprehensive which is quite relevant to the linked process including the emotional desire of work (outer enforcement), such emotional rules and regulations, and certain emotional performance like interpersonal attitudes (Grandey \& Gabriel, 2015; Gürlek, Tuna \& Yeşiltaş, 2020). According to Grandey and Gabriel (2015) and Sayre, Grandey and Chi (2020), other researchers on the same subject also have described two relevant aspects which are major ones to know the emotional labor. The first one is relevant to the individual and work, the individual who has features to be adjusted in as per the emotional tendency to perform work like the outspoken, positive thinking, and certain emotions like management techniques and skills. This aspect confirms that if the person fits in the job then there will be less effort for emotional management. This may cause the additional anxieties for employees while chasing their assigned tasks through hard work and diligence.

According to other researchers like Lam, Huo and Chen (2018), this shows the right comparison among the person-work and such person-organization is a very crucial factor to have the cordial relation with clients, particularly as the employee thinking as their job requirement and as per the value in the organization as it is maybe considered as one of the main features to sell to the customer. That is why, it very important to understand the characteristics and selection of truly spirited employees towards their job and organization, as this kind of action can be performed even with little effort (Dahiya, 2017; Lin, Koopmann \& Wang \& Hou, 2020). The second aspect is related to the reason of emotion as it is a tool which is used by the employee as a technique to smooth his or her emotional feelings as per the requirement set by the organization after the performance analysis (Glomb, Bhave, Miner \& Wall, 2011; Lin et al., 2020). Nowadays, studies 
highly focused to elaborate the importance of the emotional labor to attain the desired/required performance through service and client delighted experience (Bhave \& Glomb, 2016; Grandey \& Gabriel, 2015; Lam, Huo \& Chen, 2018; Xu, Cao \& Huo, 2020), the selection of the emotional labor management techniques are directly relevant to service and its experience of concerned employees.

The deep action is being considered one of the effective techniques for emotional management as its fruitful for the marketing peoples as they can attain right response or feedback from direct customer and their enhanced level of satisfaction (Delpechitre \& Beeler, 2018; Hur, Han, Yoo \& Moon, 2015; Alsakarneh, Hong, Eneizan \& Kharabsheh, 2019). The surface action, when being used separately is considerably unresponsive in the way of quality of work and its performance and customer level of satisfaction (Bhave \& Glomb, 2016). Although, management of emotional techniques may have certain benefits in the way of the organizational level of outcomes, like the consumer level of satisfaction and a true contribution to building a sales-related environment as it is considered by the employees a real-time sales pressure (Satpathy, Mishra \& Mohapatra, 2014; Singh \& Glavin, 2017). Previous literature showed that emotional labor had both positive and negative effects on employee job engagement (Bakker \& Leiter, 2010; Demerouti, Bakker, Nachreiner \& Schaufeli, 2001; Mauno, Ruokolainen, Kinnunen \& Bloom, 2016; Lu \& Guy, 2014; Schreurs, Emmerik, Broeck \& Guenter, 2014). Lazanyi, (2010) examines that emotional labor has a positive correlation with life satisfaction. Gopalan, Culbertson and Leiva (2013) examines the consequences that emotional labor harms the life satisfaction of the individuals in different perspectives.

Figure 1 Hypothesized Research Model

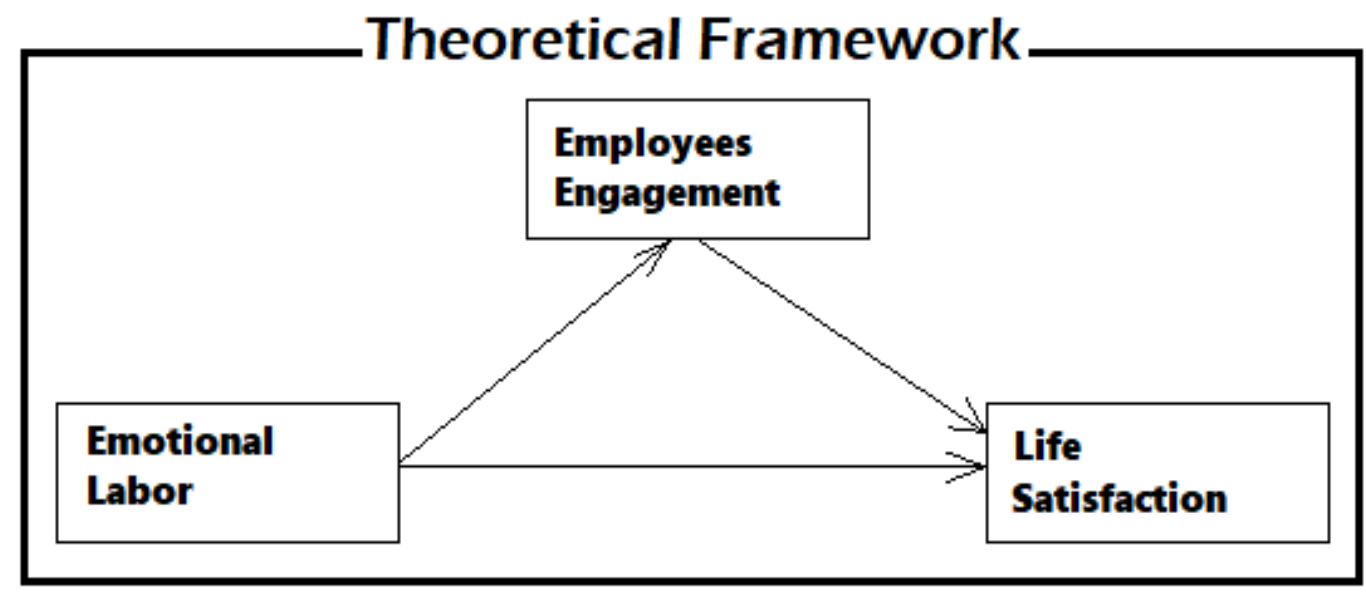

\section{Research Hypothesis}

H1: There is a relationship between emotional labor and life satisfaction

H2: Emotional labor has an impact on employee engagement

H3: Employee engagement has a positive impact on life satisfaction

H4: Employee engagement mediates relationship between emotional labor and life satisfaction 


\section{RESEARCH METHODOLOGY}

\section{Target Population \& Sample}

The target population of current studies has consisted of officers (OG-III and above) of banks located at Lahore, Pakistan. A sample of the current research has consisted of 314 officers rank employees are selected randomly by using the statistical formula for calculating accurate sample size.

\section{Scale \& Measurements}

The employee job engagement scale has consisted of 18 statements that were adopted by Rich, LePine and Crawford (2010). Emotional labor is scale has consisted of 16 statements which are adopted from Chu and Murrmann's (2006). The life satisfaction scale has consisted of the 05 statements which are adopted from Diener, Emmons, Larsen and Griffin (1985) that are widely recommended.

Table 1

Reliability Statistics

\begin{tabular}{lc}
\hline \multicolumn{1}{c}{ Variables Name } & Alpha of Reliability \\
\hline Employee Job Engagement & 0.88 \\
Emotional Labor & 0.84 \\
Life Satisfaction & 0.87 \\
\hline
\end{tabular}

The reliability statistics helps in providing the information about the internal consistency among measures used for collecting and measuring the response about the research variables. Data is reliable if the value of Cronbach's Alpha is greater than 0.60 . Table 1 indicated that all values of Cronbach's Alpha are greater than 0.60. Consequently, the data is reliable for all the variables.

\section{RESULTS \& DISCUSSIONS}

This section offered the results of the study as obtained through statistical procedures in order to examine the relationships among research variables under consideration to reach the study conclusion.

Table 2

Correlations Analysis

\begin{tabular}{lcc}
\hline & Job Engagement & Emotional Labor \\
\hline Employee Job Engagement & 1 & \\
Emotional Labor & $-0.35^{* *}$ & 1 \\
Life Satisfaction & $0.45^{* *}$ & $-0.31^{* *}$ \\
\hline
\end{tabular}

**. Correlation is significant at the 0.01 level (2-tailed)

Table 2 provides the nature of correlation i.e., either it is positive or negative. Emotional labor is negatively correlated with the employee job engagement and its value of " $\mathrm{r}$ " is $-0.35^{* *}$. Life satisfaction is positively correlated with employee job engagement and its value of " $\mathrm{r}$ " is $-0.45^{* *}$ and is negatively correlated with emotional labor and its value of " $\mathrm{r}$ " is $0.31^{* *}$ and thus offer vital 
information. The correlation analysis helps in providing the information about the association among the research variables under consideration with respect to the strength and directions of relationships. This study also offered suitable information in deciding relationship with regard to association among the research variables (employees job engagement, emotional labor and life satisfaction) which were aimed to examine in the context of the banking sector in Lahore, Pakistan.

Table 3

Correlations Analysis

\begin{tabular}{lccccc}
\hline & $\beta$ & SE & F & $\mathrm{R}^{2}$ & Decision \\
\hline $\begin{array}{l}\text { Path c (Step 1) } \\
\text { Outcome: Life Satisfaction }\end{array}$ & & & & & \\
$\begin{array}{l}\text { Predictor: Emotional Labor } \\
\text { Step 2 (Path a) }\end{array}$ & -0.32 & .086 & 72.74 & 0.29 & $0.000<0.01$ \\
$\begin{array}{l}\text { Outcome: Job Engagement } \\
\text { Predictor: Emotional Labor }\end{array}$ & & & & & \\
Step 3 A (Path b) \& Step 3 B (Path c') & -0.34 & 0.088 & 132.45 & 0.31 & $0.000<0.01$ \\
Outcome: LS, Predictor: JE & 0.43 & 0.091 & 134.31 & 0.37 & $0.000<0.01$ \\
Mediator: Job Engagement & 0.39 & 0.077 & & & $0.016<0.10$ \\
Predictor: Emotional Labor & -0.18 & 0.087 & & & $0.000<0.01$ \\
\hline \begin{tabular}{l} 
P<0.01, P<0.05, P<0.10 \\
\hline
\end{tabular}
\end{tabular}

$\mathrm{P}<0.01, \mathrm{P}<0.05, \mathrm{P}<0.10$

Table 3 provides the values of regression analysis. For the relationship between emotional labor and life satisfaction, the Value of $F$ is 72.74 and $\mathrm{R} 2=0.29$ and Value of $\beta=-0.32$. value of $\mathrm{p}<0.01$, So hypothesis 1 about the relationship of emotional labor and life satisfaction is accepted. This result is similar to the result of previous research (Gopalan et al., 2013). For the relationship of Emotional labor with employee engagement, the Value of $\mathrm{F}$ is 132.45 and $\mathrm{R} 2=0.31$ and Value of $\beta=-0.34$. value of $\mathrm{p}<0.01$, So hypothesis 2 about this relationship is also accepted. This result is similar to the results of previous researches (Demerouti et al., 2001, Mauno et al., 2016, Lu \& Guy 2014, Schreurs et al., 2014). For relationship of employee engagement with life satisfaction, the value of $F$ is 134.31 and $R 2=0.37$ and the Value of $\beta=0.43$. value of $p<0.01$, So hypothesis 3 about this relationship is accepted. This result is similar to results of the previous researches (Hakanen, \& Schaufeli, 2012; Mache et al., 2014). For checking mediation influence of employee job engagement for the relation of emotional labor with life satisfaction. First of all, the current study checks the direct relationships i.e., emotional labor with life satisfaction, emotional labor with the employee job engagement, and the employee job engagement with the life satisfaction respectively. These three results are significant. For checking the mediation effect, the current research regresses the emotional labor with employee job engagement on life satisfaction. It is seen that Value of $\beta$ is reduced from -0.32 to -0.18 . This value describes that partial mediation exists.

\section{CONCLUSION}

The employee engagement is an emerging trend for the organizations and life satisfaction is an established variable on which researches are continued emerges since its existence. The current research focuses on these two variables along with emotional labor. For conducting the research, current research gathering data from bank officers. Results indicate that emotional labor has a 
negative significant impact on the life satisfaction and employee job engagement. Furthermore, employee job engagement partially mediating the relationship of the emotional labor with life satisfaction. There are some limitations to the research. Data is collected at a single time point from the respondents. Some other important cities are not included in survey. Some potential antecedents of life satisfaction (perceived organizational support, job satisfaction, psychological contract breach is not included in this research. This study offered significant theoretical and empirical evidences in deciding relationships among research variables un study. This research is based on employees of banks of Lahore. For genializing the result this kind of research may include the broad sample like Islamabad, Bahawalpur, Faisalabad, Multan, and Karachi that may help in extracting the significant information. It is also recommended that this type of the research may also be conducted on the telecom, education, textile sector as well as in education sector to validate results. It may also be interesting to compare outcomes of these results city wise.

\section{REFERENCES}

Albrecht, S. L., \& Marty, A. (2020). The Personality, self-efficacy and job resources and their associations with employee engagement, affective commitment \& turnover intentions. The International Journal of Human Resource Management, 31(5), 657-681.

Alexander, P. M. (2020). The Strategies to Reduce the Voluntary Employee Turnover. The PhD thesis.

Alsakarneh, A., Hong, S. C., Eneizan, B., \& Kharabsheh, K. A. (2019). Exploring the relationship between emotional labor and performance in the Jordanian insurance industry. Current Psychology, 38(5), 1140-1151.

Aşan, Ö., \& Erenler, E. (2008). The Relationship between job satisfaction and the life satisfaction. Suleyman Demirel University Journal of Economics and Administrative Sciences, 13(2), 203-216.

Avsaroglu, S, Deniz, M. E, \& Kahraman, A. (2005). Teknik ogretmenlerde yasam doyumu, is doyumu ve mesleki tukenmislik duzeylerinin incelenmesi. Selcuk Universitesi Sosyal Bilimler Enstitusu Dergisi, 14, 115129.

Avşaroğlu, S., \& Okutan, H. (2018). Zihin engelli çocuğu olan ailelerin yaşam doyumları, iyimserlik ve psikolojik belirti düzeylerinin incelenmesi. Manas Sosyal Araştırmalar Dergisi, 7(1), 59-76.

Bakker, A. B., \& Leiter, M. P. (Eds.). (2010). Work engagement: A handbook of essential theory and research. Psychology press.

Bates, S. T. (2004). 'Getting engaged': The Review. The HR Magazine, (2004). Vol 49, No 2, pp, 44-51.

Bhave, D. P., \& Glomb, T. M. (2016). The role of occupational emotional labor requirements on the surface acting-job satisfaction relationship. Journal of Management, 42(3), 722-741.

Bilal, R. U., Yawar, R. B., \& Zaman, H. M. F. (2020). Relationship of personal resilience and job satisfaction through the lens of employee engagement. Academic Journal of Social Sciences, 4(2), 364-376.

Brayfield, A.H., Strate, M.W., \& Wells, R.V. (1957) Interrelationships among Measures of JobSatisfaction and General Satisfaction, Journal of Applied Psychology, 41, $201-220$

Campaña, J. C., Giménez, J. I., \& Molina, J. A. (2020). Self-employed and Employed Mothers in Latin American Families: Are There Differences in Paid Work, Unpaid Work, and Child Care? Journal of Family and Economic Issues, 41(1), 52-69. 
Chu, K. H. L., \& Murrmann, S. K. (2006). Development and validation of the hospitality emotional labor scale. Tourism Management, 27(6), 1181-1191.

Chug, P. K. (2017). Enhancing Employee Engagement Through a Novel Mathematical Model in the Hospitality Sector of India. Prabandhan: Indian Journal of Management, 10(8), 7-24.

Chung, K. S., \& Kim, M. (2017). Anger factors impacting on life satisfaction of mothers with young children in Korea: Does mother's age matter? Personality and individual differences, 104, 190-194.

Crabtree, S. (2011). What employees worldwide have in common. The Gallup Management Journal.

Dahiya, A. (2017). Extroversion and emotional labour: A study on organized retail sector. International Journal of Research in Commerce \& Management, 8(4).

Delpechitre, D., \& Beeler, L. (2018). Faking it: salesperson emotional intelligence's influence on emotional labor strategies and customer outcomes. Journal of Business \& Industrial Marketing.

Demerouti, E., Bakker, A.B., Nachreiner, F., \& Schaufeli, W.B. (2001). "The Job Demandsresources Model of Burnout,” Journal of Applied Psychology, 86, 499- 512.

Diener, E. D., Emmons, R. A., Larsen, R. J., \& Griffin, S. (1985). The satisfaction with life scale. Journal of personality assessment, 49(1), 71-75.

Diener, E., Lucas, R. E., Oishi, S., \& Suh, E. M. (2002). Looking up and looking down: Weighting good and bad information in life satisfaction judgments. Personality and Social Psychology Bulletin, 28(4), 437-445.

Ekinci, N. E. (2018). Examining Effect of Participating to Recreational Activities on Loneliness Level of Middle School Students. Universal Journal of Educational Research, 6(9), 18871890.

Gallup (2017). https://www.gallup.com/workplace/238085/state-american-workplace-report 2017.aspx.

Glint, T. (2018). The State of Employee Engagement in 2018 in Greenberg, J. (1987). A taxonomy of organizational justice theories. Academy of Management Review 12, 9-22.

Glomb, T. M., Bhave, D. P., Miner, A. G., \& Wall, M. (2011). Doing good, feeling good: Examining the role of the organizational citizenship behaviors in changing mood. Personnel Psychology, 64(1), 191-223.

Gopalan, N., Culbertson, S. S., \& Leiva, P. I. (2013). Explaining emotional labor's relationships with emotional exhaustion and life satisfaction: Moderating role of perceived autonomy. Universitas psychologica, 12(2), 347-356.

Grandey, A. A., \& Gabriel, A. S. (2015). Emotional labor at a crossroads: Where do we go from here? Annual Review of Organizational Psychology, 2(1), 323-349.

Gürlek, M., Tuna, A. A., \& Yeşiltaş, M. (2020). İşveren Markası İşe Adanmayı Nasıl Etkiler? Duygusal Emeğin Aracılı Rolü.Afyon Kocatepe Üniversitesi Sosyal Bilimler Dergisi, 22(2), 593-614.

Hakanen, J. J., \& Schaufeli, W. B. (2012). Do burnout and work engagement predict depressive symptoms and life satisfaction? A three-wave seven-year prospective study. Journal of affective disorders, 141(2-3), 415-424.

Hakanen, J. J., Schaufeli, W. B., \& Ahola, K. (2008). The Job Demands-Resources model: A three-year cross-lagged study of burnout, depression, commitment, and work engagement. Work \& Stress, 22(3), 224-241. 
Harwood, C. G., Knight, C. J., Thrower, S. N., \& Berrow, S. R. (2019). Advancing the study of parental involvement to optimise the psychosocial development and experiences of young athletes. Psychology of Sport and Exercise, 42, 66-73.

Hochschild, A. R. (1979). Emotion work, feeling rules, and social structure. American journal of sociology, 85(3), 551-575.

Hochschild, A. R. W. (1983). The managed heart. The Berkeley: The University of the California Press.

Hu, Q., Schaufeli, W. B., \& Taris, T. W. (2016). Extending the job demands-resources model with guanxi exchange. Journal of Managerial Psychology, 31(1), 127-140.

Hur, W. M., Han, S. J., Yoo, J. J., \& Moon, T. W. (2015). The moderating role of perceived organizational support on the relationship between emotional labor and job-related outcomes. Management Decision.

Kahn, W. (1990). Psychological conditions of personal engagement and disengagement at work. Academy of management journal, 33(4), 692-724.

Karakuş, Ö., \& Kirlioğlu, M. (2019). Engelli bir çocuğa sahip olmanın getirdiği yaşam deneyimleri: Anneler üzerinden nitel araştırma. Selçuk Üniversitesi Sosyal Bilimler Enstitüsü Dergisi, (41), 96-112.

Khalaf, R. K. A., Hmoud, H. Y., \& Obeidat, B. (2019). Reviewing the Mediating Role of Job Satisfaction on Effect of Employee Engagement on Organizational Performance. Journal of Social Sciences, 8(1), 7-23.

Khan, M., \& Lakshmi, N. (2018). Mediating Role of Employee Engagement in the Relationship between Perceived Supervisor Support and Job Satisfaction. Asian Journal of Management, 9(1), 189-196.

Korkmaz, C. B. (2019). Sağlık çalışanlarının örgütsel sinizm düzeyleri ile iş tatminleri arasındaki ilişki: Diyarbakır Selahaddin Eyyübi Devlet Hastanesi örneği (Master's thesis, Trakya Üniversitesi Sağlık Bilimleri Enstitüsü).

Lam, W., Huo, Y., \& Chen, Z. (2018). Who is fit to serve? Person-job/organization fit, emotional labor, and customer service performance. Human Resource Management, 57(2), 483-497.

Lazanyi, K. (2010). Who Benefits From Emotional Labour?. APSTRACT: Applied Studies in Agribusiness and Commerce, 4(1033-2016-84110), 71-74.

Lee, J. Y., Rocco, T. S., \& Shuck, B. (2020). What is a resource: Toward a taxonomy of resources for employee engagement? Human Resource Development Review, 19(1), 5-38.

Lightsey, O. R., McGhee, R., Ervin, A., Rarey, E. B., \& Powell, K. (2013). Self-efficacy for affect regulation as a predictor of future life satisfaction and moderator of the negative affectLife satisfaction relationship. Journal of Happiness Studies, 14(1), 1-18.

Lin, W., Koopmann, J., \& Wang, M. (2020). How does workplace helping behavior step up or slack off? Integrating enrichment-based and depletion-based perspectives. Journal of Management, 46(3), 385-413.

Lu X. \& Guy M.E. (2014) how emotional labour and ethic leadership affect job engagement for Chinese public servants? Public Personnel Management, 43(1), 3-24.

Macey, W. H., \& Schneider, B. (2008). The meaning of employee engagement. Industrial and organizational Psychology, 1(1), 3-30.

Mache, S., Vitzthum, K., Klapp, B. F., \& Danzer, G. (2014). Surgeons' work engagement: Influencing factors and relations to job and life satisfaction. The surgeon, 12(4), 181-190.

Mann, A., \& Harter, J. (2016). The worldwide employee engagement crisis. Gallup Business Journal, 7, 1-5. 
Mauno, S., Ruokolainen, M., Kinnunen, U., \& Bloom, J. (2016). Emotional labour and work engagement among nurses: examining perceived compassion, leadership and work ethic as stress buffers. Journal of advanced nursing, 72(5), 1169-1181.

Mungthanaworakun, N., Sujitjorn, S., Suwansak, T., Wongthongdee, S., Prempraneerach, Y., \& Rugchoochip, K. (2020). Employee Engagement and Achievement Perception of Thai Synchrotron Institute. Open Journal of Business and Management, 8(2), 639-648.

Özsoy, E., Uslu, O., \& Öztürk, O. (2014). Who are happier at work and in life? Public sector versus private sector: A research on Turkish employees. International Journal of Recent Advances in Organizational Behaviour and Decision Sciences, 1(2), 148-160.

Rich, B., LePine, J., \& Crawford, E. (2010). Job engagement: Antecedents and effects on job performance. The Academy of Management Journal, 53, 617-635.

Rodríguez, T., Cabrera, I., Palomino, M., León, J., \& Esteban, C. (2020). Evaluación psicométrica de la versión en español del Dimensions of Anger Reactions-5 (DAR-5) en universitarios. Ansiedad y Estrés.

Saks, A. M. (2006). Antecedents and consequences of employee engagement. Journal of managerial psychology. 21(7), 600-619.

Satpathy, I., Mishra, S., \& Mohapatra, M. (2014). Employee Job Satisfaction-A Review of Litreature. IRS'C. International Journal of Multidisciplinary Research and Social \& Management Sciences, 2(4).

Sayre, G. M., Grandey, A. A., \& Chi, N. W. (2020). From cheery to "cheers"? Regulating emotions at work and alcohol consumption after work. Journal of applied psychology, 105(6), 597.

Schreurs, B., Emmerik, I. J., Broeck, A., \& Guenter, H. (2014). Work values and work engagement within teams: The mediating role of need satisfaction. Group Dynamics: Theory, Research, and Practice, 18(4), 267.

Singh, D., \& Glavin, P. (2017). An occupational portrait of emotional labor requirements and their health consequences for workers. Work and occupations, 44(4), 424-466.

Slåtten, T., \& Mehmetoglu, M. (2011). Antecedents and effects of engaged frontline employees. Managing Service Quality: An International Journal.

Sundaray, B. K. (2011). Employee engagement: A Driver of organizational effectiveness. European Journal of Business and Management, 3(8), 53-59.

Sung, H., \& Giannakopoulos, E., (1994). The Relationship of Satisfaction with Life to Personality Characteristics, Journal of Psychology Interdisciplinary \& Applied, 128(5), 547.

Swanberg, J. E., McKechnie, S. P., Ojha, M. U., \& James, J. B. (2011). Schedule control, supervisor support and work engagement: A winning combination for workers in hourly jobs? Journal of Vocational Behavior, 79(3), 613-624.

Thomas, J., Côté, J., \& Deakin, J. (2008). Understanding dropout and prolonged engagement in adolescent competitive sport. Psychology of sport and exercise, 9(5), 645-662.

Upadyaya, K., Vartiainen, M., \& Salmela, K. (2016). From job demands and resources to work engagement, burnout, life satisfaction, depressive symptoms, and occupational health. Burnout research, 3(4), 101-108.

Veloso, C., Peralta, A., Gil, F., Cornejo, Á., \& Castro, S. (2015). Workers training: Impact of a program based on positive psychology and social skills, on life satisfaction, job satisfaction and organizational climate Capacitación en trabajadores: Impacto de un programa, basado en psicología positiva y habilidades socia.

Veloso, S., Matos, M. G., Palmeira, A., Martins, S., Fonseca, H., \& Diniz, J. A. (2015). Weight management program based on self-determination theory: comparing parents-child data. Psicologia, Saúde e Doenças, 16(1), 86-99. 
Vural, M., Yalcinkaya, E. Y., Celik, E. C., Gunduz, B., Bozan, A., \& Erhan, B. (2020). Assessment of quality of life in relation to spasticity severity and socio-demographic and clinical factors among patients with spinal cord injury. The Journal of Spinal Cord Medicine, 43(2), 193200.

Watson, T. (2012). 2012 Global Workforce Study: engagement at risk: Driving strong performance in a volatile global environment.

Welbourne, T. M. (2007). Employee engagement: Beyond the fad and into the executive suite.

$\mathrm{Xu}$, J., \& Thomas, H. C. (2011). How can leaders achieve high employee engagement? Leadership and Organization Development Journal, 32(4), 399-416.

$\mathrm{Xu}, \mathrm{S}$. T., Cao, Z. C., \& Huo, Y. (2020). Antecedents and outcomes of emotional labour in hospitality and tourism: A meta-analysis. Tourism Management, 79, 104099.

Yllmaz, E., Yılmaz, E., \& Karaca, F. (2008). U“" niversite o ${ }^{\circ} \mathrm{g}$ rencilerinin sosyal destek ve yalnızlık du" zeylerinin incelenmesi [Examining the level of social support and loneliness of university students]. Genel Tip Dergisi, 18(2), 71-79.

Yu, G. B., Sirgy, M. J., Bosnjak, M., \& Lee, D. J. (2020). A Preregistered Study of the Effect of Shopping Satisfaction during Leisure Travel on Satisfaction with Life Overall: Mitigating Role of Financial Concerns. Journal of Travel Research, 0047287520933688. 